\title{
SISTEM INFORMASI LAYANAN ADMINISTRASI KEPEGAWAIN BERBASIS LOKAL AREA NETWORK (LAN)
}

\author{
Yuliadi $^{*}$, Rodianto $^{2}$, Rusdan ${ }^{3}$, Dedy Sofyan MZ. ${ }^{4}$ \\ ${ }^{1,2}$ Teknik Informatika, Universitas Teknologi Sumbawa \\ ${ }^{3,4}$ Sistem Informasi, Universitas Nahdlatul Ulama NTB Mataram \\ yuliadi@uts.ac.id ${ }^{*}$
}

\begin{abstract}
Abstrak: Penggunaan sistem informasi untuk membantu kinerja organisasi semakin dibutuhkan. Dengan didukung oleh kecanggihan teknologi informasi, telah memungkinkan pengembangan sistem informasi yang semakin handal. Pegawai merupakan subjek penting dalam sebuah organisasi. Manusia memiliki kemampuan untuk menggerakkan semua sumber daya organisasi yang ada. Apabila pegawai diperhatikan secara tepat dengan menghargai bakat-bakat, mengembangkan kemampuan, dan menggunakannya secara tepat maka organisasi akan menjadi dinamis dan berkembang. Dinas Komunikasi Informasi dan Arsip Daerah Lombok Tengah merupakan salah satu instansi pemerintah yang bertugas mengelola dan mengembangkan infrastruktur teknologi informasi dan arsip daerah Lombok Tengah. Untuk memudahkan dalam pendataan adminstrasi kepegaiwan maka dibutuhkan suatu aplikasi sistem informasi administrasi kepegawaian untuk membantu dalam mengolah data pegawai, kenaikan pangkat, kenaikan gaji berkala dan pensiun.
\end{abstract}

Kata Kunci : Teknologi Informasi, Pegawai, Administrasi, Pangkat, Gaji Berkala

\begin{abstract}
The use of information systems to help organizational performance is increasingly needed. Supported by the sophistication of information technology, it has enabled the development of an increasingly reliable information system. Employees are an important subject in an organization. Humans have the ability to move all existing organizational resources. If employees are properly cared for by appreciating talents, developing abilities, and using them appropriately, the organization will become dynamic and develop. The Central Lombok Regional Archives and Information Communication Office is one of the government agencies in charge of managing and developing the information technology infrastructure and archives of the Central Lombok region. To make it easier to collect employee administration data, an application for personnel administration information system is needed to assist in processing employee data, promotions, regular salary increases and pensions.
\end{abstract}

Keywords : Information Technology, Employees, Administration, Rank, Periodic Salaries

\section{PENDAHULUAN}

Pengolahan data yang dilakukan dengan baik dan benar akan menghasilkan informasi yang baik dan bermanfaat bagi penggunanya. Pemanfaatan sistem informasi elektronik dapat membantu suatu instansi/perusahaan untuk memudahkan pengguna dalam melakukan pengelolaan data sehingga kegiatan administrasinya dapat berjalan dengan lebih produktif, transparan, tertib, tepat, mudah, akurat, terpadu, aman dan efisien. Hal ini sejalan dengan pergeseran paradigma dari regulasi menghambat (wall regulations) menuju regulasi mendorong (enabling regulation) [1].

Dengan perkembangan teknologi yang begitu pesat sangat berpengaruh terhadap bisnis. Institusi atau perusahaan yang tidak menggunakan teknologi menjadi klah bersaing. Peningkatan penggunaan sistem informasi juga tidak terlepas dari perhatian manajemen organisasi dalam institusi atau perusahaan terhadapa betapa pentingnya informasi [2].

Sistem informasi administrasi kepegawaian adalah suatu tata cara atau prosedur tentang cara-cara mengorganisasikan dan memperlakukan orang yang bekerja sedemikian rupa sehingga mereka masingmasing mendapatkan hasil yang sebesar-besarnya dari kemampuannya. Sistem informasi yang mendukung membuat kinerja suatu instansi akan terlaksana dengan baik dan dapat menangani berbagai penginputan data dengan menggunakan teknologi informasi [3].

Pegawai merupakan subjek penting dalam sebuah organisasi. Manusia memiliki kemampuan untuk menggerakkan semua sumber daya organisasi yang ada. Tanpa adanya pegawai yang baik, organisasi akan sulit berkembang karena kekuatan setiap organisasi terletak pada pegawai yang mengelola dan menanganinya. Apabila pegawai diperhatikan secara tepat dengan menghargai bakatbakat, mengembangkan kemampuan, dan menggunakannya secara tepat maka organisasi akan menjadi dinamis dan berkembang.

Dinas Komunikasi Informasi Arsip Daerah Lombok Tengah merupakan salah satu instansi pemerintah yang bertugas mengelola dan mengembangkan infrastruktur teknologi informasi dan arsip daerah Lombok Tengah. Untuk memudahkan dalam pendataan layanan adminstrasi kepegaiwan maka dibutuhkan suatu aplikasi sistem informasi layanan administrasi kepegawaian untuk berbasis LAN yang dapat membantu dalam mengolah data pegawai, kenaikan pangkat, kenaikan gaji berkala dan pensiun.

Saat ini, kegiatan yang berkaitan dengan data pegawai, kenaikan pangkat, kenaikan gaji berkala dan pensiun dilakukan secara semi manual yang mana 
pendataan pegawai, informasi kenaikan pangkat, gaji berkala dan pensiun dilakukan secara manual dan harus dingat oleh masing-masing pegawai. Beberapa permasalahan yang terjadi,berupa beberapa kegiatan penting lambat diambil di proses karena manajemen membutuhkan waktu yang lama dalam mempelajari berbagai laporan mengenai data-data administrasi kepegawaian untuk data pegawai, kenaikan pangkat, kenaikan gaji berkala dan pensiun.

\section{TINJAUAN PUSTAKA}

a. Tinjauan Pustaka

Adapun tinjauan Pustaka yang menajdi rujukan dalam penlitian ini, yakni penelitian yang dilakukan oleh Meuthia Rachrnanlah, Hari Agung Adriantol dan Abdul Aziz yang berjudul Rancang Bangun Sistem Informasi Manajemen Kepegawaian Dengan Metode The Open Group Architecture Framework (TOGAF). Penelitian ini melakukan pengembangan sistem informasi kepegawaian dengan metode TOGAF secara online untuk membantu manajemen dalam mengelola data pegawai dan dapat mempercepat layanan informasi kepegawaian [4].

Penelitian yang dilakukan oleh Gerry Aris Munandar, dan Amarudin dengan judul Rancang Bangun Aplikasi Kepegawaian Pegawai Negeri Sipil dan Pegawai Honorer Pada Badan Kepegawaian dan Diklat Kabupaten. Penelitian ini melakukan rancang bangun aplikasi Pengelolaan data administrasi kepegawaian pada Badan Kepegawaian dan Diklat Kabupaten Pesawaran sehingga dalam pelayanan pengajuan dapat dilakukan dengan cepat dan efisien serta mengurangi waktu yang cukup lama, memperkecil kemungkinan terjadinya kesalahan dalam pencatatan dan mempercepat proses pencarian [5].

Penelitian yang dilakukan oleh Farida Yusuf yang berjudul Rancang dan Bangun Sistem Informasi Administrasi Diklat Pada PT PLN (Persero) Wilayah SULSELRABAR Berbasis Web. Penelitian ini melakukan merancang dan membangun sistem informasi administrasi diklat berbasis Web pada PT. PLN (Persero) Wilayah SULSELRABAR yang dapat mengatasi masalah tentang sulitnya mendapatkan data dan informasi terkait dengan diklat dikarenakan perusahaan memiliki banyak data yang harus diolah [6].

b. Dasar Teori

1. Sistem Informasi

Sistem informasi merupakan suatu sistem di dalam organisasi yang merupakan kombinasi dari orang-orang, fasilitas, teknologi, media, prosedur-prosedur dan pengendalian yang ditujukan untuk mendapatkan tujuan yang diinginkan [7].
2. Jaringan Komputer

Jaringan komputer memungkinkan pemakaian secara bersama data, perangkat lunak dan peralatan, sehingga kelompok kerja dapat berkomunikasi bahkan saat ini telah menggunakan jaringan global (internet) sebagai media untuk pencarian informasi dan komunikasi. Indonesia menempati peringkat ke6 terbesar di dunia dalam hal jumlah pengguna internet. Tahun 2016 pengguna internet di Indonesia mencapai 102 juta, dipredikasi tahun 2018 akan mencapai 123 juta pengguna [8].

3. Sistem Informasi Kepegawaian

Sistem informasi kepegawaian adalah suatu sistem yang saling berhubungan dan berinteraksi dengan orang bekerja dalam suatu organisasi untuk mencapai tujuan tertentu. Sistem informasi kepegawaian otomatis sudah menggunakan komputer yang dilengkapi dengan teknologi informasi. Sistem informasi administrasi kepegawaian yang bersifat client server, sehingga penggunaan data secara bersamaan dapat dilakukan.[1].

4. Sistem Informasi Administrasi Kepegawaian Sistem informasi administrasi kepegawaian didefinisikan sebagai sistem informasi terpadu, yang meliputi pendataan pegawai, pengolahan data, prosedur, tata kerja, sumber daya manusia dan teknologi informasi untuk menghasilkan informasi yang cepat, lengkap dan akurat. Adanya sistem informasi administrasi kepegawaian ini memiliki beberapa keuntungan, antara lain [9]:

a. Menghasilkan informasi tentang data pegawai.

b. Memudahkan pengolahan data pegawai sehingga dapat mendukung kelancaran pelaksanaan dan fungsi administrasi kepegawaian.

c. Memudahkan pekerjaan subbagian administrasi dan dokumentasi dalam membuat laporan.

\section{METODE}

Dalam pengembangan aplikasi ini menggunakan metode SDLC (System Development Life Cycle) dengan model proses waterfall. Semua tahapan pengembangan hanya diadopsi menggunakan beberapa tahapan, adalah sebagai berikut [10]:

a. Rekayasa Sistem

Kegiatan untuk melakukan pengumpulan kebutuhan mengenai data maupun informasi yang dibutuhkan oleh pengguna berdasarkan observasi dan wawancara pihak terkait serta studi kepustakaan untuk kebutuhan pengembangan. Dalam mendapatkan kebutuhan tersebut ada beberapa kegiatan yang dilakukan penulis 
diantaranya, yakni Studi Lapangan (Field Reserch) dan Studi Pustaka

b. Analisa Kebutuhan

Analisis merupakan proses kegiatan utama dalam pengembangan perangkat untuk menspesifikasi kebutuhan yang diperlukan dalam pengembangan. Analisa kebutuhan adalah proses untuk melakukan analisis atas informasi kebutuhan yang didapat pada kegiatan sebelumnya untuk mengetahui kebutuhan sistem yang tepat diperlukan oleh perusahaan. Kebutuhan tersebut berupa kebutuhan utama dan pendukung dalam pengembangan sistem informasi.

c. Perancangan Sistem

Tahap perancangan adalah tahap menterjemahkan kebutuhan sistem yang sudah dibuat pada tahap analisis. Desain prosesnya dengan Data Flow Diagram (DFD) dan Desain data dengan Entity Relationship Diagram (ERD).

\section{HASIL DAN PEMBAHASAN}

Ada beberapa langkah-langkah dalam pembuatan Sistem Informasi Layanan Administrasi Kepegawaian Berbasis LAN ini adalah sebagai berikut:

a. Melakukan instalasi tools pemrograman dan

DBMS (Database Management System).

b. Membuat file database dengan tool yang sudah diinstal.

c. Setelah itu baru desain tampilan dan melakukan pemrograman.

Setelah program Sistem Informasi Layanan Administrasi Kepegawaian Berbasis LAN ini jadi kemudian selanjutnya dijalankan untuk pengujian program. Untuk menjalankan dan memulai program aplikasi ini dapat dilakukan dengan mengklik 2 (dua) kali (double click) pada shortcut DUK.Exe. Didalam sub bab ini menjelaskanan tentang tampilan form yangsudah dibuat menggunakan tools yang sudah ditentukan. Berikut ini tampilan-tampilan antar muka yang ada dalam program yang dibuat adalah:

a. Tampilan Form Login

Tampilan form menu utama ini merupakan tampilan awal saat progam dijalankan. Pengguna yang ingin mengakses program ini sepenuhnya harus melewati form login. Adapun tampilan form login dari apikasi ini adalah sebagai berikut:

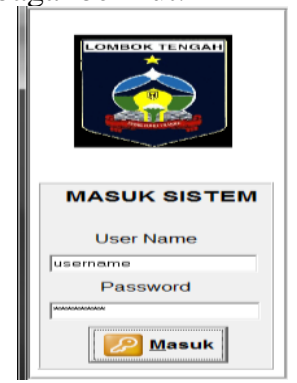

Gambar 1. Tampilan Form Login b. Tampilan Form Data Unit Kerja

Pada tampilan form unit kerja ini berfungsi untuk penginputan data unit kerja baru pada aplikasi ini adalah sebagai berikut:

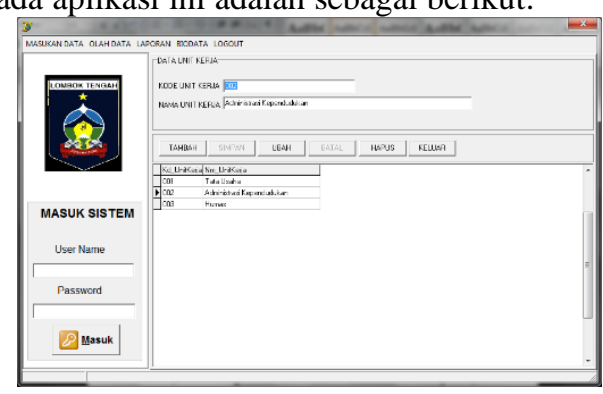

Gambar 2. Tampilan Form Data Unit Kerja

c. Tampilan Form Olah Data Kenaikan Pangkat

Pada tampilan form olah data kenaikan pangkat ini berfungsi untuk penginputan data olah data kenaikan pangkat baru, menghapus dan mengubah data master. Adapun tampilan form olah data kenaikan pangkat ini adalah sebagai berikut:

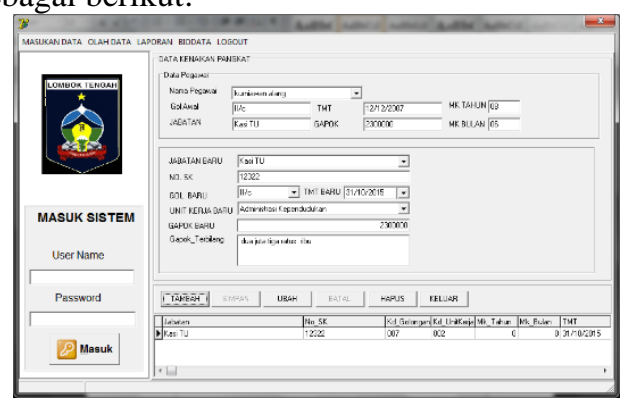

Gambar 3. Tampilan Form Olah Data Kenaikan Pangkat

d. Tampilan Form Olah Data Kenaikan Gaji Berkala

Pada tampilan form olah data kenaikan gaji berkala ini berfungsi untuk penginputan data olah data kenaikan gaji berkala, menghapus dan mengubah data. Adapun tampilan form data olah data kenaikan gaji berkala apikasi ini adalah sebagai berikut:

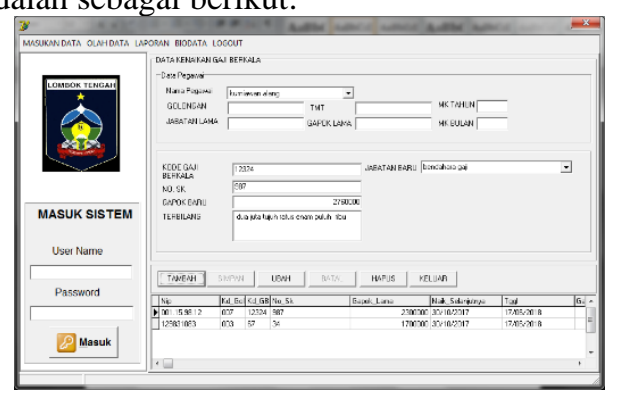

Gambar 4. Tampilan Form Olah Data Kenaikan Gaji Berkala

e. Tampilan Olah Data Pensiun

Pada tampilan form olah data pensiun ini berfungsi untuk penginputan data olah data pensiun baru, menghapus dan mengubah data. 
Adapun tampilan form data olah data pensiun apikasi ini adalah sebagai berikut:

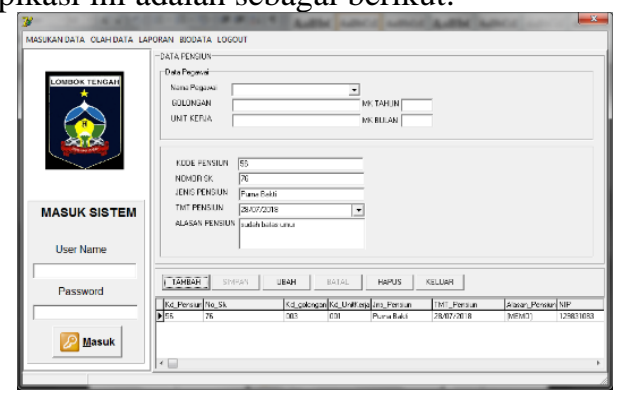

Gambar 5. Tampilan Form Olah Data Kenaikan Gaji Berkala

\section{KESIMPULAN DAN SARAN}

Aplikasi sistem informasi layanan administrasi kepegawaian berbasis LAN digunakan pengelolaan data kepegawaian, kenaikan pangkat dan gaji berkala serta status pension pegawai. Agar pimpinan mudah mengetahui apakah seorang pegawai tersebut layak untuk kenaikan pangkat dan gaji berkala atau tidak serta tamengetahu pegawai yang akan memasuki purnabakti (pensiun). Admin sebagai pengelola sistem dapat mencari informasi data pegawai yang akan naik pangkat, naik gaji berkala dan pensiun sesuai periodenya, Karena Penyimpanan di lakukan secara secara komputerisasi pada setiap proses memasukan data.

Dalam pengembangan aplikasi sistem informasi layanan administrasi kepegawaian berbasis LAN untuk pengembangan selanjutnya di buat menggunakan pemrograman berbasis android. Yang dilengkapi dilengkapi dengan SMS center untuk informasi ke pegawai yang naik pangkat, gaji berkala dan pensiun. Dan adanya integrasid data dengan bagian pengelola keuangan daerah bila pegawai bnaik pangkat sehingga secara otomatis akan mengikuti kenaikan gaji pegawai tersebut dan tidak perlu di rapel.

\section{DAFTAR PUSTAKA}

[1] P. K. Handayani, "Sistem Informasi Administrasi Data Kepegawaian Pada Bagian Personalia Pt. Xyz," Simetris J. Tek. Mesin, Elektro dan Ilmu Komput., vol. 7, no. 1, p. 373, 2016, doi: 10.24176/simet.v7i1.527.

[2] Marwaziah, "Rancang Bangun Sistem Informasi Kepegawaian (Studi Kasus Bank Muamalat Indonesia)," Universitas Islam Negeri Syarif Hidayatullah, 2011.

[3] F. H. Sofika Enggari, Larissa Navia Rani, "Pengembangan Sistem Informasi Administrasi Kepegawaian Pada Fakultas Ilmu Sosial Ilmu Politik Universitas Andalas Padang Berbasis Web," vol. 2, no. 3, 2015, [Online]. Available: http://lppm.upiyptk.ac.id/komtekinfo/index.php/K OMTEKINFO/article/view/158/115.

[4] A. A. Meuthia Rachmaniah, Hari Agung Adrianto, "Rancang Bangun Sistem Informasi Manajemen
Kepegawaian Dengan Metode The Open Group Architecture Framework (Toga F), J. Ilmu Pertan. Indones., vol. 16, no. 3, pp. 164-172, 2011, [Online]. Available: https://repository.ipb.ac.id/jspui/bitstream/123456 789/69840/1/JIPI 2011.MTR pdf.pdf.

[5] A. Munandar, Gerry Aris, "Rancang Bangun Aplikasi Kepegawaian," J. TEKNOINFO, vol. 11, no. 2, pp. 54-58, 2017, [Online]. Available: https://core.ac.uk/download/pdf/229543066.pdf.

[6] F. Yusuf, "Rancang dan Bangun Sistem Informasi Administrasi Diklat Pada PT. PLN (Persero) Wilayah SULSELRABAR Berbasis Web," Teknosains Media Inf. Sains Dan Teknol., vol. 12, no. 2, pp. 210-228, 2019, doi: 10.24252/teknosains.v12i2.7600.

[7] J. Simarmata, Rekayasa Perangkat Lunak. Yogyakarta: Andi Offset, 2010.

[8] F. Ardianto, B. Alfarezi, and A. J. Komputer, "Rancang Bangun Jaringan Server Mikrotik Untuk Jaringan Local Area Network ( LAN ) dan Internet,” pp. 134-137, 2018, [Online]. Available: http://repository.um-

palembang.ac.id/id/eprint/3529/2/2018f-1-24Feby-Ardianto.pdf.

[9] J. L. Mawarizka Deviera, Sulistiowati, "Rancang Bangun Sistem Informasi Administrasi Kepegawaian Pada PT. Pancaran Semangat Jaya," Jsika, vol. 6, no. 2, pp. 1-17, 2016, [Online]. Available:

https://jurnal.dinamika.ac.id/index.php/jsika/articl e/download/624/656.

[10] A. F. Eko Prianto, Anton Yudhana, "Analisis Perancangan Aplikasi Kepegawaian dan Kegiatan Berbasis Android," 2017, pp. 63-68, [Online]. Available:

https://media.neliti.com/media/publications/1748 07-ID-analisis-perancangan-aplikasiadministra.pdf. 